\title{
Financial Performance Comparison of Islamic and conventional banks in the United Arab Emirates (UAE)
}

\author{
Mosab I. Tabash ${ }^{1}$ Ali T. Yahya ${ }^{2}$, Asif Akhtar $^{3}$ \\ ${ }^{1}$ College of Business, \\ Al Ain University of Science and Technology, \\ P.O. Box: 64141, Al Ain, United Arab Emirates (UAE), \\ Mosab.tabash@aau.ac.ae \\ 2,3 Department of Business Administration, \\ Aligarh Muslim University, Aligarh, UP 202002, India
}

\begin{abstract}
This paper examines the financial performance of Islamic and commercial banks in the United Arab Emirates (UAE). The paper gives an empirical insights and comparisons between the performance of Islamic and conventional banking sectors. The sample of the study consists of 5 fully-fledged Islamic banks and 14 conventional banks working in the UAE under the period 2011-2014. The study uses descriptive analysis, correlation, independent sample $t$ test and multiple regression analysis to assess the performance and to compare between both types of banks. The Return on Assets (ROA) is used as proxy for profitability for both types of banks while bank size (log A), liquidity, capital adequacy, financial risk and operating efficiency as proxies for financial performance for both types of banks. The results showed that there is no significant difference between Islamic banks and conventional banks in terms of profitability (ROA) while there is a significant difference between Islamic and conventional banks in terms of liquidity, operation efficiency, capital adequacy, and financial risk. Further, the results indicated that the Islamic banks have higher operating efficiency, bank size and more liquidity than their counterparts of UAE. However, conventional banks are found to have better capital adequacy ratio than Islamic banks. In terms of financial risk, Islamic banks are found to have higher five times than conventional banks which may reflect challenges in the area of risk management in Islamic banks.
\end{abstract}

Keywords: Financial performance, Islamic banks, Conventional banks, ROA, UAE.

JEL Classification: A10, E60, G21

http://dx.doi.org/10.30585/icabml-cp.v1i1.39

2523-6547 - Copyright: (C) 2017 The Authors. This is an open access article distributed under the terms of the Creative Commons Attribution License, which permits unrestricted use, distribution, and reproduction in any medium, provided the original author and source are credited. 


\section{INTRODUCTION}

The growth of any economy to a great extent depends largely on the performance of its banking sector. The banking sector works as intermediary linking two parties; who gave the funds and the other party who invested the funds for productive purposes and thereby contributing to economic development. In the financial world, there are two types of banks. One is called conventional banks and the other is called Islamic banks. The main difference between the two bank types is the philosophy in which the banking sector depends on. In Islamic banking sector, the interest rate is totally prohibited even it is small or large. Therefore, sometimes, it is called interest-free banking. In the other side, conventional banks are based totally on interest. So, it is called interest-based banks. Nowadays, Islamic banks and conventional banks are working together in a dual regulatory environment and there is an intense competition between them in attracting potential customers and fulfilling their expectations and developing new instruments and modes of financing which in turn benefits the economy in the long-term.

In the United Arab Emirates, the two types of banks are working together in a very competitive environment. Recently, Islamic banks enhance their position in the world and particularly in the UAE during the global financial crisis 2008. Islamic banks are partially affected by the crisis and outperformed than commercial banks (Athanasoglou et al. 2008, 2; Tabash and Dhankar, 2014). Also, from another side, Islamic banks contributed positively to the growth of the economy of UAE (Tabash and Anagreh, 2017).

The United Arab Emirates (UAE) gives more attention and support for Islamic banking industry. For example, Dubai Emirate is working on to become a hub for Islamic finance industry in the world. The UAE government supports the Islamic banking industry growth through its strategic plan 2021 (Emirates Diary, 2015). Currently, there are twenty-three local banks and twenty-two international banks working in the UAE. Out of the twenty three local banks, 5 are fully-fledged Islamic banks working under Islamic standards as appeared in appendix (1) and the rest banks have both system, Islamic and traditional operations (Emirates Diary, 2015).

There are not many studies that have been conducted to examine the performance comparisons between Islamic and conventional banks in UAE. So, the objective of this study is to determine the factors that are affecting Islamic banks and conventional banks profitability of UAE. The present study is divided into six sections. Section 1 gives an introduction of the study. Section 2 shows the objectives and importance of the study. Section 3 presents the hypotheses of the study. Section 4 provides the relevant literature on the banking sector performance. Section 5 describes the methodology used to analyze the data. Section 6 analyses the data and discusses the results. Finally, conclusion is given in section 7 .

\section{OBJECTIVES AND IMPORTANCE OF THE STUDY}

The current study shows the factors that affect the performance of UAE banking sector (Islamic and conventional banks). The study is very vital in terms of discussing the financial ratios that are crucial for the profitability of Islamic and conventional banks of UAE which it is vital for the progress of the economy and welfare of the UAE society in particular and Gulf Cooperation Council GCC in general. The study tries to achieve the following objectives:

2523-6547 - Copyright: (C) 2017 The Authors. This is an open access article distributed under the terms of the Creative Commons Attribution License, which permits unrestricted use, distribution, and reproduction in any medium, provided the original author and source are credited. 
1. To assess the impact of Capital Adequacy (CA) on the financial performance of Islamic and conventional banks in UAE.

2. To assess the impact of Bank Size (Log A) on financial performance of Islamic and conventional banks in UAE.

3. To assess the impact of Operating Efficiency (OE) on financial performance of Islamic and conventional banks in UAE

4. To assess the impact of Financial Risk (FR) on financial performance of Islamic and conventional banks in UAE.

5. To assess the impact of liquidity (LQ) on financial performance of Islamic and conventional banks in UAE.

\section{STUDY HYPOTHESES}

The hypotheses of the study are developed as below.

H1: Liquidity has significant impact on financial performance of Islamic and conventional banks in UAE.

$\mathrm{H} 2$ : Financial risk has significant impact on financial performance of Islamic and conventional banks in UAE.

H3: Operating efficiency has significant impact on financial performance of Islamic and conventional banks in UAE.

H4: Bank size has significant impact on financial performance of Islamic and conventional banks in UAE.

H5: Capital adequacy has significant impact on financial performance of Islamic and conventional banks in UAE.

\section{LITERATURE REVIEW}

There are many studies that examined the performance ratios of conventional banks and linked their performance with economic development of the country. There is no doubt that the financial performance evaluation is an important issue among managers, investors and shareholders. It enhances the bank's stability and performance. It offers a signal to depositors to keep or withdraw their funds. However, Islamic and conventional banks exhibit differences in funding and activity structures. Indeed, Islamic banks have neither the same principles and regulatory structure nor the same experiences as conventional banks (Zarrouk, Ben Jedidia, and Moualhi, 2016). There are also differences in terms of financial intermediation. Islamic banks do not act as simple lenders. They combined commercial banking activities and investment banking operations (Al-Kassim, 2005). Islamic banking concentrates on risk and return sharing, while the conventional bank is "debt based" and characterized by risk transfer (Hasan and Dridi, 2010). The literature work in this area is divided into different approaches. Some studies concentrate on the performance of conventional banks, and others in the performance of Islamic banks. The third approach is a comparative approach between the Islamic and conventional systems.

2523-6547 - Copyright: (C) 2017 The Authors. This is an open access article distributed under the terms of the Creative Commons Attribution License, which permits unrestricted use, distribution, and reproduction in any medium, provided the original author and source are credited. 
For conventional banks' performance studies, Bordelean and Graham (2010) evaluated the relationship between liquid asset holding and profitability for a panel of Canadian and U. S. banks for the period of 19972009. Their study found that there is a non-linear relationship between liquid assets and profitability. The study concluded that profitability is improved for banks that hold some liquid assets but excess of holding liquid assets diminished the bank's profitability.

Another study of Kumbirai and Webb (2010) investigated the liquidity, profitability and credit quality performance of South Africa's commercial banks for the period of 2005-2009. The study found that the global financial crisis had adverse effect on South African banks which had resulted into falling profitability, low liquidity and deteriorating credit quality of the banking sector. In the year of 2011, Aremu, A. (2011) evaluated the liquidity and asset management of Nigerian banks for the period of 1975-2009 using different liquidity ratios. Liabilities to Assets, Loans to Assets, Loans to Deposits, Cash to total liabilities and Log (total assets) are representing size of bank. The study found that out of three banks, two are more liquid than the third one. The study concluded that Central Bank of Nigeria $(\mathrm{CBN})$ remains liquid at all times to avoid the liquidity crisis.

In the same year, Khrawish (2011) identified the determinants of commercial banks performance in Jordan for the period of 2000-2010. The study found significant and positive relationship between ROA and bank size, total liabilities to total equity, total equity to total assets and net interest margin. The results showed negative relationship between ROA and annual growth in GDP and inflation rate of the commercial banks. The study concluded that internal factors are the major performance determinants of Jordanian banks in comparison to external factors.

Further, Olweny and Shipho (2011) assessed the effect of bank specific factors of profitability of 38 Kenyan commercial banks for the period of 2002-2008. The study found that bank specific factors like capital adequacy, asset quality, liquidity and efficiency related factors had a significant impact on profitability while none of the market factors had a significant impact on profitability on Kenyan banks. The study concluded that revenue diversification; reduction in operational cost can increase the profitability of Kenyan commercial banks. For Islamic banks' performance studies, Bashir (2000) examined the determinants of the financial performance for 14 Islamic banks across 8 Middle Eastern countries between 1993 and 1998 using cross-country bank-level data. The results of his study concluded that the profitability indicators of the Islamic banks are positively and significantly correlated to the bank capital. Furthermore, the empirical study of Hassan and Bashir (2003) on Islamic banks' performance in 21 countries over the period 1994-2001 showed that the bank profitability is high when the capital increases across the years. However, Wasiuzzaman and Tarmizi (2010), on his study about the financial performance of 16 Islamic banks in Malaysia, note that the capital has "an inverse relationship" with the banking profitability. The impact of bank activity on Islamic banks profitability remains inconclusive. The loan portfolios ratio is significantly positively related to bank profitability (Bashir, 2000). In a study of 20 Islamic banking systems, C`ihák and Hesse (2008) demonstrated that the return on assets (ROA) is significantly affected by the total Equity-to-Total Assets (Equity/ TA) and Total Loans-to-Total assets ratios.

For Islamic and conventional banking comparative studies, some studies show that Islamic banks are more profitable than conventional banks. Ansari and Khalil-ur-Rehman (2011) compared five Islamic banks and five conventional banks in Pakistan during the period 2005-2009. They concluded that Islamic banks are much superior because they could increase their market shares, and their deposits increase profitability more than that of conventional banks. Kader and Asarpota (2007) assessed and compared the performances of three UAE Islamic

2523-6547 - Copyright: (C) 2017 The Authors. This is an open access article distributed under the terms of the Creative Commons Attribution License, which permits unrestricted use, distribution, and reproduction in any medium, provided the original author and source are credited. 
banks to five conventional banks during the period 2000-2004. They found that Islamic banks are relatively more profitable, less risky and also less liquid than their conventional bank. Other studies have showed that Islamic banks are less profitable than their conventional counterparts. Compared to a group of five conventional banks in Pakistan during 2003-2008, the Meezan Bank Limited was less profitable and less efficient but more solvent and so less risky (C`ihák and Hesse, 2008). Hanif et al. (2012) selected a sample of 22 conventional banks and Islamic banks in Pakistan and argued that conventional banking is better than Islamic banks in terms of profitability and liquidity.

Moreover, there is no difference between the overall efficiency of Islamic and conventional banks in term of profit, as suggested by Bader et al. (2008). In this respect, Samad and Hassan (2000) discussed the performance (profitability, liquidity, risk and solvency and also community involvement) of Bank Islam Malaysia Berhad (BIMB) over the period 1984-1997. The bank's performance is compared with two conventional banks as well as with eight conventional banks in two periods (1984-1989 and 1990-1997). The results showed that the bank is relatively less risky, more solvent and more liquid compared to conventional banks. Moreover, for the period 1991-2000, the empirical findings of Samad (2004) imply that there is no significant difference in profitability and liquidity performance between the two sets of banks. As well, Akhter et al. (2011) indicated that there is likely no significant difference between interest-based banking and interest-free banking with respect to profitability, while there is divergence in liquidity and credit performance.

In another study, Adnan and Ramlan (2015) in their study titled as the profitability of Islamic and conventional bank: Case study in Malaysia showed that Islamic banks are more profitable than conventional banks in the context of Malaysian banking industry. Further, they concluded that Return on Equity (ROE) is a determinant factor for conventional banks; meanwhile ROE and ROA are determinant factors of profitability for Islamic banks in the case of Malaysia. Another study of Malaysia, Tarmizi and Wasiuzzaman (2017) in their study concluded that the capital and asset quality have an inverse relationship with bank profitability while liquidity and operational efficiency have a positive influence on Islamic banks. Further, Zahid, Hussein, and Azizuddin (2016) examined the performance between Islamic and commercial banks in Malaysia. They revealed that Islamic banks are better than commercial banks in liquidity and profitability. Furthermore, Kamaruddin, B., and Mohammed, R. (2013) explained in their study also from Malaysia that the liquidity and capital adequacy for Islamic banks is better than conventional banks.

On the basis of above literature, it is identified that various studies have been carried out relating to the performance of commercial banks. Not many studies have been carried out to measure the performance of Islamic banks on different dimensions. Whether the commercial banks or Islamic banks are doing and performing well on each dimensions or not is being to be studied. Thus, there is a literature gap which needs to be fulfilled. The present study is an attempt in this direction especially in the conventional and Islamic banks of UAE.

\section{DATA AND METHODOLOGY}

\subsection{Sample and Data collection}

The sample of this study is for 5 full-fledged Islamic banks and 14 conventional banks of United Arab Emirates (UAE) as shown in appendix (1). Data were collected for Islamic and commercial banks in UAE covering the period of 2010 - 2014. The main data source is the Bank Scope database for commercial banks. The data set for Islamic banks is extracted from Islamic Banks and Financial Institutions Information (IBIS) database for all Islamic banks' in the world. Other data sources are fetched from annual reports for both banks working in UAE.

5.2 Data Analysis Methods

2523-6547 - Copyright: (C 2017 The Authors. This is an open access article distributed under the terms of the Creative Commons Attribution License, which permits unrestricted use, distribution, and reproduction in any medium, provided the original author and source are credited. 
The quantitative method is utilized in this study. All financial ratios, hypotheses test and statistical tests are done using E-views software version7.0.

\subsection{Variables}

There are 6 variables used in the study. One variable is used as dependent variables and five variables are used as independent variables. The dependent and independent variables are as shown in Figure 1.

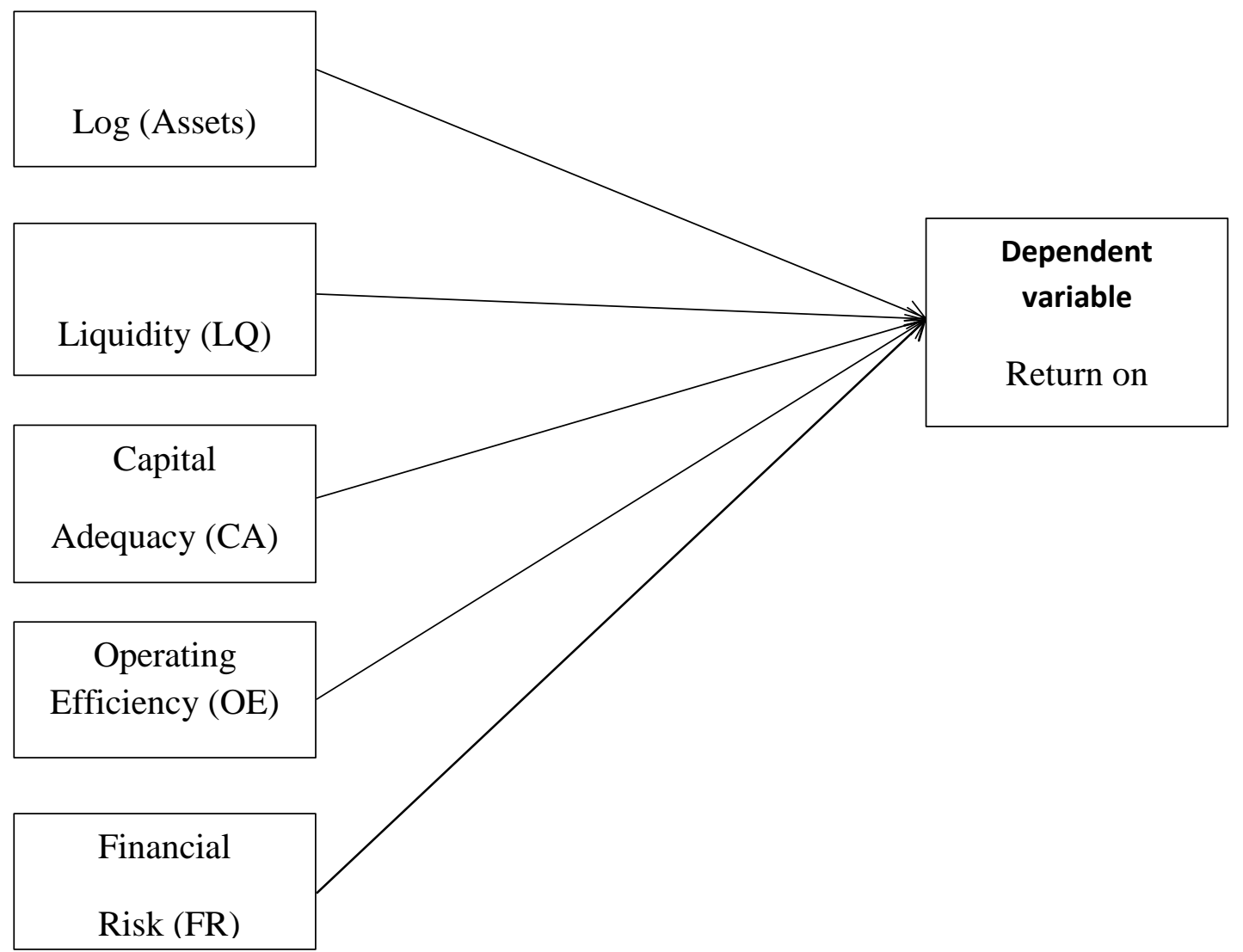

Figure 1: Study framework for all variables

\section{- $\quad$ Dependent variables}

Based on the literature review, we select Return on Assets (ROA) as a measure of profitability of Islamic and conventional banks. Return on assets (ROA) is a well-known measure for banks profitability to assess and evaluate the ability of the banks to generate return from its assets to maintain profit.

\section{- Independent variables}

The bank-specific variables used in the study are: asset size, capital adequacy, financial risk, liquidity management and operational efficiency as shown in Table 1.

Asset size: The asset size variable is a common measure in determining the bank profitability. The total assets of bank are used as proxy for bank size. The banks size is taken by the logarithm of total assets (log AS).

Capital adequacy (CA): The capital adequacy ratio presents the strength of Islamic banks capital and is one of the basic ratios that determine the strength of capital. 
Financial Risk (FR): The financial risk ratio that shows the percentage of a company's total assets that are provided through liabilities.

Liquidity Management (LM): To measure the liquidity of Islamic banks, liquid assets to total assets ratio is used. The higher the ratio the more liquid is the bank. The one major cause of bank failure is inadequate liquidity.

Operational Efficiency (OE): To measure the operation efficiency of Islamic banks, the ratio of cost to total income is used. The rationale behind using this measure is that it reflects the cost of running the bank as a percentage of income.

Table 1: Variables definitions and notations

\begin{tabular}{|c|c|c|c|}
\hline & Variable & Measure used & Notation \\
\hline $\begin{array}{l}\text { Dependent } \\
\text { variables }\end{array}$ & Profitability & Return on assets $(\mathrm{ROA})=$ Profits $/$ total assets & ROA \\
\hline \multirow{5}{*}{$\begin{array}{c}\text { Independent } \\
\text { variables }\end{array}$} & \multirow{5}{*}{$\begin{array}{c}\text { Bank-Specific } \\
\text { Factors }\end{array}$} & Asset size $=$ Natural logarithm of total assets & $\log (\mathrm{AS})$ \\
\hline & & Capital adequacy $=$ Equity /total assets & $\mathrm{CA}$ \\
\hline & & Operating efficiency $=$ Cost $/$ income & $\mathrm{OE}$ \\
\hline & & Liquidity Management: Liquid assets/total assets & LQ \\
\hline & & Financial Risk : Total liabilities/ Total assets & FR \\
\hline
\end{tabular}

5.4 Study model

In this study, a model is developed to identify the relationship between the financial performance of Islamic and conventional banks in UAE. The used model consists of $\mathrm{N}=1, \ldots, \mathrm{n}$, observed at each of $\mathrm{T}$ time periods, $\mathrm{T}=$ $1, \ldots, \mathrm{t}$. In the dataset, the total observation is $\mathrm{n} \times \mathrm{t}$. The basic framework for the data is defined as per the following regression model. Further, in this study, we will check the impact of liquidity, capital adequacy, financial risk, operating efficiency and bank size on the profitability of both Islamic and commercial banks in the context of UAE by using panel data regression model. But before applying the regression analysis, data has been examined against outliers to be valid to the regression model. Therefore, correlation analysis has been done for all variables. As a rule of thumb, if the correlation coefficients between two regressors are less than 0.8 , it means there is no multicollinearity between variables. After correlation test, we can proceed to regression models. The current study depends on using regression model to assess the relationship between ROA, donated as Y, and five definite independent variables, denoted as LQ, CA, OE, $\log (\mathrm{A})$ and FR. Researchers found one restriction during the data collection for the mentioned variables, which is unavailability of data for longer periods particularly for Islamic banks. The regression model for the three variables is written below.

$\mathrm{ROA}_{n t}=\beta 0+\beta 1 \mathrm{OE}+\beta 2 \log (\mathrm{A})+\beta 3 \mathrm{LQ}+\beta 4 \mathrm{CA}+\beta 5 \mathrm{FR}+\varepsilon$ 
Where:

ROA: Dependent variable to measure profitability of Islamic and commercial banks of UAE

$\alpha$ : constant

$\beta 1$ - $\beta 5$ : Coefficients of independent variables

$\varepsilon$ : Error term.

OE, Log (A), LQ, CA and FR: Independent variables to measure the performance of Islamic and commercial banking sector of UAE.

\section{DATA ANALYSIS AND RESULTS}

This section gives analysis part for the performance of Islamic banks and conventional banks of UAE. Descriptive analysis, correlation analysis and regression model are given in this analysis.

\subsection{Descriptive Statistics Analysis}

Table 2 summarizes the descriptive statistics for the conventional and Islamic banks and it is divided into two parts; Panel A conventional banks, and Panels B for Islamic banks. In Table 2, the difference between the maximum and the minimum values for ROA are high for both conventional and Islamic banks in the UAE. The mean ROA is almost same for conventional and Islamic banks. From another perspective, it can be observed that the Islamic banks have higher operating efficiency, bank size and more liquid than conventional banks. However, conventional banks are found to have better capital adequacy ratio than Islamic banks. In terms of financial risk, Islamic banks are found to have higher five times than conventional which may reflect challenges of the area of risk management in Islamic banks. 
Table 2: Descriptive Statistics for Islamic and conventional banks of UAE

Panel A: Conventional banks

\begin{tabular}{|l|l|l|l|l|l|l|}
\hline & ROA & OE & LQ & LOGA & FR & CA \\
\hline Mean & 2.14 & 33.32 & 17.05 & 4.13 & 16.60 & 0.17 \\
\hline Median & 2.06 & 32.58 & 15.00 & 4.00 & 16.22 & 0.16 \\
\hline Maximum & 5.15 & 52.55 & 34.00 & 5.00 & 29.62 & 0.3 \\
\hline Minimum & 0.57 & 18.73 & 6.00 & 3.50 & 9.84 & 0.1 \\
\hline Std. Dev. & 0.96 & 7.86 & 7.37 & 0.52 & 4.61 & 0.05 \\
\hline Observations & 56 & 56 & 56 & 56 & 56 & 56 \\
\hline Panel B: Islamic banks & & & & & & \\
\hline Mean & 2.26 & 72.29 & 28.23 & 5.58 & 86.17 & 13.50 \\
\hline Median & 1.44 & 65.20 & 30.28 & 5.60 & 88.11 & 11.89 \\
\hline Maximum & 6.76 & 156.78 & 38.84 & 5.6 & 92.96 & 24.48 \\
\hline Minimum & 0.29 & 33.03 & 14.13 & 5.5 & 75.15 & 6.92 \\
\hline Std. Dev. & 2.05 & 24.99 & 7.78 & 0.04 & 4.67 & 4.70 \\
\hline
\end{tabular}




\subsection{Correlation}

Table 3 and 4 show the correlation coefficients between explanatory variables. As a rule of thumb, multicollinearity is to be considered as a big problem in the regression analysis if the pair-wise correlation coefficients between two regressors are in more than 0.8. It is clear from the Table 3 and 4 that the correlation coefficients between variables were less than 0.8. This indicates that there is no multicollinearity between variables for both Islamic and conventional banks in the UAE. It is also clear from Table 3 and 4 a positive and negative relationship between independent variables and dependent variables.

Table 3: Correlation matrix for conventional banks

\begin{tabular}{|l|c|l|l|l|l|}
\hline \multicolumn{7}{|l|}{ LQ } & \multicolumn{1}{l|}{ CA } & FR & LOGAS & OE \\
\hline LM & 1.00 & & & & \\
\hline CA & -0.30 & 1.00 & & & \\
\hline AQ & 0.49 & 0.05 & 1.00 & & \\
\hline LOGAS & 0.35 & -0.12 & 0.52 & 1.00 & \\
\hline OE & 0.22 & 0.45 & 0.062 & .24 & 1.00 \\
\hline
\end{tabular}

Table 4: Correlation matrix for Islamic banks

\begin{tabular}{|l|r|r|r|r|l|}
\hline \multicolumn{7}{|l|}{ LQ } & \multicolumn{1}{l|}{ CA } & \multicolumn{2}{l|}{ FR } & LOGAS & OE \\
\hline & 1.00 & & & & \\
\hline LM & -0.21 & 1.00 & & & \\
\hline CA & 0.41 & 0.20 & 1.00 & & \\
\hline AQ & 0.66 & 0.05 & 0.46 & 1.00 & \\
\hline LOGAS & 0.48 & -0.27 & -0.05 & 0.15 & \\
\hline OE & & & & & \\
\hline
\end{tabular}

\subsection{Differences between Islamic and conventional banks in the UAE}

The results of Table 5 for the financial performance between Islamic and conventional banks using the independent sample t-test show that there is no significant difference in the financial performance measured by ROA and was found to be highly insignificant with p-value of 0.73 which is more than (0.05) level of significance. This result is consistent with other studies done by (Samad and Hassan (2000), Akhter et al. (2011), Samad (2004) ) but it is not consistent with other studies that show Islamic banks are more profitable than conventional banks like (Zahid, Z., Hussin, S. and Azizuddin (2016), Mohammed, R. and Kamaruddin, B., 
(2013)). However, In terms of other variables (Bank Size, liquidity, Capital Adequacy, Financial Risk and Efficiency) were found to be highly significant with p-values of 0.000 which is less than (0.05) level of significance. This means that Islamic banks have higher operating efficiency, bank size, more liquid than their counterparts. Also, financial risk of Islamic banks is found higher five times than conventional banks. These results are consistent with other studies like (Samad and Hassan (2000), Ansari and Khalil-ur-Rehman (2011)).

Table 5: Comparison between mean of Islamic and conventional banks of UAE

\begin{tabular}{|c|c|c|c|c|c|c|}
\hline \multicolumn{7}{|c|}{ Independent Samples Test } \\
\hline \multirow{3}{*}{ Variables } & \multicolumn{2}{|c|}{$\begin{array}{lrr}\text { Levene's } & \text { Test } & \text { for } \\
\text { Equality } & & \text { of } \\
\text { Variances } & & \end{array}$} & \multicolumn{4}{|c|}{ t-test for Equality of Means } \\
\hline & \multirow[t]{2}{*}{$\mathrm{F}$} & \multirow[t]{2}{*}{ Sig. } & \multirow[t]{2}{*}{$\mathrm{t}$} & \multirow[t]{2}{*}{$\begin{array}{l}\text { Sig. (2- } \\
\text { tailed) }\end{array}$} & \multicolumn{2}{|c|}{$\begin{array}{l}95 \% \text { Confidence } \\
\text { Interval of the } \\
\text { Difference }\end{array}$} \\
\hline & & & & & Lower & Upper \\
\hline $\mathrm{ROA}$ & 15.466 & 0 & -0.346 & 0.73 & -0.808 & 0.569 \\
\hline LOG & 81.162 & 0 & -12.474 & 0.000 & -1.683 & -1.22 \\
\hline FR & 0.003 & 0.955 & -57.711 & 0.000 & -71.975 & -67.171 \\
\hline $\mathrm{CA}$ & 69.366 & 0 & -21.472 & 0.000 & -14.534 & -12.066 \\
\hline LQ & 134.814 & 0 & -27.246 & 0.000 & -30.074 & -25.975 \\
\hline $\mathrm{OE}$ & 16.92 & 0 & -10.42 & 0.000 & -46.411 & -31.511 \\
\hline
\end{tabular}

\subsection{Regression Analysis}

Panel Least Squares (PLS) regression model is used to test the link between the dependent and independent variables for both Islamic and commercial banks of UAE. From Table 6 and Table 7, the outputs of Panel Least Squares regression analysis show that the value of R-square is $49 \%$ for Islamic banks and $44 \%$ for conventional banks. It means that the independent variables for the two banking sectors are accountable to $49 \%$ and $44 \%$ of the variability of Islamic and conventional banks profitability respectively. The coefficient of LQ was found to be negative and insignificant since P value is more than (5\%) level of significance for Islamic banks. While, the P value of LQ in conventional banks is less than $1 \%$, thus it shows a positive and significant relationship of liquid assets to the profits of conventional banks in UAE. Therefore, we accept the first hypothesis for conventional banks and reject if for Islamic banks.

The Results also show that Financial Risk (FR) is negatively related with Return on Assets (ROA) in conventional banks' model and positive in Islamic banks' model. The P value of Financial Risk (FR) is more than $5 \%$ level of significance in both types of banks so there is no significant impact of financial risk

2523-6547 - Copyright: (C) 2017 The Authors. This is an open access article distributed under the terms of the Creative Commons Attribution License, which permits unrestricted use, distribution, and reproduction in any medium, provided the original author and source are credited. 
on financial performance measured by ROA. Therefore, we reject the second hypothesis for Islamic and conventional banks.

The coefficient of operating efficiency OE was found to be positive in both models (both types of banks) and the $\mathrm{P}$ value in the Islamic banks model is less than $1 \%$, thus it means positive and a significant relationship of operating efficiency over the profits of Islamic banks in UAE. While, the P value of the other model is more than 5\% level of significance; it represents an insignificant relationship of operating efficiency on the financial performance of Conventional banks in UAE. Therefore, we accept the third hypothesis for Islamic banks while reject it for conventional banks.

The coefficient of other variables (bank size $(\log \mathrm{A})$ and capital adequacy) are positively related with Return on Assets (ROA) in both types of banks and the P value are more than 5\% level of significance in both models that means no significant impact of bank size and capital adequacy on the financial performance of Islamic and conventional banks in UAE. Therefore, we reject the fourth and fifth hypotheses for both types of banks.

Table 6: Regression results of Islamic banks of UAE

\begin{tabular}{|l|l|l|l|}
\hline & \multicolumn{3}{|l|}{} \\
\hline Variables & Coefficients & t-Statistic & Prob. \\
\hline Constant & -97.48388 & -1.069704 & 0.3028 \\
\hline OE & 0.019223 & 3.017760 & 0.0092 \\
\hline LQ & 0.102644 & -0.197357 & 0.8464 \\
\hline Log A & 11.10309 & 1.560747 & 0.1409 \\
\hline FR & 0.761146 & 0.007000 & 0.9945 \\
\hline CA & 0.799932 & -0.087462 & 0.9315 \\
\hline R Squared & 0.484085 & & \\
\hline $\begin{array}{l}\text { Adjusted R } \\
\text { Squared }\end{array}$ & 0.299830 & & \\
\hline
\end{tabular}


Table 7: Regression results of conventional banks of UAE

\begin{tabular}{|l|l|l|l|}
\hline & \multicolumn{2}{|l|}{} \\
\hline Variables & Coefficients & t-Statistic & Prob. \\
\hline Constant & -1.441303 & -0.867203 & 0.3900 \\
\hline OE & 0.007487 & 0.541875 & 0.5903 \\
\hline LQ & 6.107992 & 4.139872 & 0.0001 \\
\hline Log A & 0.183119 & 0.711890 & 0.4798 \\
\hline FR & -0.027725 & -0.074385 & 0.9410 \\
\hline CA & 12.01107 & 0.321897 & 0.7489 \\
\hline R Squared & 0.434322 & & \\
\hline $\begin{array}{l}\text { Adjusted R } \\
\text { Squared }\end{array}$ & 0.377754 & & \\
\hline
\end{tabular}




\section{CONCLUSION}

The study examined the factors that affecting the performance of both banking sector in the United Arab Emirates (UAE). We used return on assets (ROA) as proxy for Islamic banks and conventional banks. Bank size, capital adequacy, liquidity management, financial risk, and operating efficiency are used as independent variables. The results of the independent sample $t$ test showed that there is no significant difference between Islamic banks and conventional banks in terms of profitability (ROA) while there is a significant difference between Islamic and conventional banks in terms of liquidity, operation efficiency, capital adequacy, and financial risk. The results of this study is very important to policy makers of UAE to improve the performance of banking sector by setting corrective measures and regulations for best risk management practices which results in improving the efficiency of UAE banking sector and then the economic development of the UAE. 
1. List of Islamic banks of UAE

\begin{tabular}{|c|c|}
\hline No & Bank Name \\
\hline 1 & DUBAI ISLAMIC BANK (DIB) \\
\hline 2 & ABU DHABI ISLAMIC BANK (ADIB) \\
\hline 3 & SHARJAH EMIRATES BANK \\
\hline 4 & EMIRATES ISLAMIC BANK \\
\hline 5 & AJMAN BANK \\
\hline
\end{tabular}

\section{List of commercial banks of UAE}

\begin{tabular}{|l|l|}
\hline \multicolumn{1}{|c|}{ No } & \\
\hline 1 & EMIRATES NBD PJSC \\
\hline 2 & NATIONAL BANK OF ABU DHABI \\
\hline 3 & FIRST GULF BANK \\
\hline 4 & ABU DHABI COMMERCIAL BANK \\
\hline 5 & MASHREQBANK PSC \\
\hline 6 & NATIONAL BANK OF RAS AL-KHAIMAH (P.S.C.) (THE) - RAKBANK \\
\hline 7 & UNION NATIONAL BANK \\
\hline 8 & COMMERCIAL BANK OF DUBAI P.S.C. \\
\hline 12 & NATIONAL BANK OF FUJAIRAH PJSC \\
\hline 13 & \\
\hline 10 & NATIONAL BANK OF UMM AL-QAIWAIN PSC \\
\hline 12 & \\
\hline
\end{tabular}

2523-6547 - Copyright: (C) 2017 The Authors. This is an open access article distributed under the terms of the Creative Commons Attribution License, which permits unrestricted use, distribution, and reproduction in any medium, provided the original author and source are credited. 


\section{References}

Adnan, M., and Ramlan, H., (2015), The Profitability of Islamic and Conventional Bank: Case study in Malaysia, Procedia Economics and Finance, 35, pp. 359 - 367.

Aremu A. M. (2011), "A Perspective on Liquidity and Asset Management of Commercial Banks in Nigeria: Evidence from Some Selected Banks", Journal of Emerging Trends in Economics and Management Science, Vol. 2 (6), pp. 454-460.

Athanasoglou, P. P., Brissimis, S. N., Delis, M. D., (2008),"Bank-specific, Industry specific and Macroeconomic Determinants of Bank Profitability”, Journal of International Financial Markets, Institutions and Money, Issue 18, pp. 121-136.

Al-Kassim, F. (2005), "The profitability of Islamic and conventional banking in the GCCcountries: a comparative study", unpublished paper.

Ansari, S. and Khalil-ur-Rehman, S.Z. (2011), "Comparative financial performance of existing Islamic Banks and contemporary conventional banks in Pakistan", 2nd International Conference on Economics, Business and Management, IACSIT Press, Singapore.

Bader, M.K.I., Mohamad, S., Ariff, M. and Hassan, T. (2008), "Cost, revenue and profit efficiency of Islamic verses Conventional banks: international evidence using data envelopment analysis”, Islamic Economic Studies, Vol. 15 No. 2, pp. 23-76.

Bashir, A.M. (2000), "Determinants of profitability and rates of return margins in Islamic banks: some evidence from the Middle East", paper presented at the ERF Seventh Annual Conference, Amman, Jordan, 26-29 October, available at: www.erf.org.eg/CMS/uploads/pdf/1185358321_finance4.pdf (accessed 5 July 2011).

Bashir, A.M. and Hassan, M.K. (2003), "Determinants of Islamic banking profitability", paper presented at the ERF 10th Annual Conference, Marrakech, Morocco, 16-18 December, available at: www.erf.org.eg/tenthconf/Financial_Markets_Presented/Kabir_Bashir.pdf (accessed 6 July 2011).

Beck, T., Demirgüç-Kunt, A. and Merrouche, O. (2013), "Islamic vs. conventional banking: business model, efficiency and stability”, Journal of Banking and Finance, Vol. 37 No. 2, pp. 433-447.

Bordelean E. and Graham C., (2010), "Impact of Liquidity on Bank Profitability”, Bank of Canada Working Paper No. 2010-xx, pp. 1-24.

C` ihák, M. and Hesse, H. (2008), “Islamic Banks and financial stability: an empirical analysis”, IMF Working Paper 08/16.

Emirates Diary, Islamic banks in UAE report, 2015, Available at http://emiratesdiary.com/uae-tips/list-of-islamicbanks-in-uae\#ixzz4OOVVgTyg, accessed on 19 Sept. 2016.

Hanif, M., Tariq, M., Tahir, A. and Wajeeh-ul, M. (2012), "Comparative performance study of conventional and Islamic banking in Pakistan”, International Research Journal of Finance and Economic, Vol. 83, pp. 62-72.

Hasan, M. and Dridi, J. (2010), “The effects of the global crisis on Islamic and conventional banks: a comparative study", IMF Working Paper WP/10/201.

2523-6547 - Copyright: (C) 2017 The Authors. This is an open access article distributed under the terms of the Creative Commons Attribution License, which permits unrestricted use, distribution, and reproduction in any medium, provided the original author and source are credited. 
Kamaruddin, B. H., and Mohd, R. (2013), “CAMEL analysis of Islamic banking and conventional banking in Malaysia”, Business and Management Quarterly Review, 4(3), 81-89.

Khrawish, H., (2011), “Determinants of Commercial Bank Performance: Evidence from Jordan”, International Research Journal of Finance and Economics, Issue- 81, pp. 148-159.

Kumbirai, M. and Webb, R. (2010), “A Financial Ratio Analysis of Commercial Bank Performance in South Africa”, African Review of Economics and Finance, Vol. 2(1), pp. 30-53.

Nimalathasan, B. (2008). A comparative study of financial performance of banking sector in bangladesh - an application of camels rating system, 2(2), 141-152.

Olweny, T. and Shipo T., (2011), "Effects of Banking Sectoral factors on the Profitability of Commercial Banks in Kenya", Economics and Finance Review, Vol. 1(15), pp. 1-30.

Tabash, M. I., and Anagreh S. A., (2017), "Do Islamic banks contribute to growth of the economy? Evidence from United Arab Emirates (UAE)", Banks and Bank Systems, 12(1), pp. 113-118, doi:10.21511/bbs.12(11).2017.03.

Tabash, M. I., and Dhankar R. S. (2014), "The Impact of Global Financial Crisis on the Stability of Islamic Banks: Empirical Evidence", Journal of Islamic Banking and Finance, 2(1), pp. 367-388.

Tarmizi, H., and Wasiuzzaman, S. (2017), Profitability of Islamic Banks in Malaysia: An Empirical Analysis, Banking and Finance, 6(4), 53-68.

Zarrouk, H., Ben Jedidia, K., \& Moualhi, M. (2016). Is Islamic bank profitability driven by same forces as conventional banks? International Journal of Islamic and Middle Eastern Finance and Management, 9(1), 46-66. https://doi.org/10.1108/IMEFM-12-2014-0120.

Wasiuzzaman, S. and Tarmizi, H.A. (2010), "Profitability of Islamic banks in Malaysia: an empirical analysis", Journal of Islamic Economics, Banking and Finance, Vol. 53, p. 68.

Zahid, Z., Hussin, S. and Azizuddin, A. (2016), Performance comparison of Islamic and commercial banks in Malaysia, AIP Conference Proceedings 1782, doi: 10.1063/1.4966070

2523-6547 - Copyright: (C) 2017 The Authors. This is an open access article distributed under the terms of the Creative Commons Attribution License, which permits unrestricted use, distribution, and reproduction in any medium, provided the original author and source are credited. 
2523-6547 - Copyright: (C) 2017 The Authors. This is an open access article distributed under the terms of the Creative Commons Attribution License, which permits unrestricted use, distribution, and reproduction in any medium, provided the original author and source are credited. 